\title{
A New Record of Coleophora virgaureae (Lepidoptera: Gelechioidea: Coleophoridae) from Korea
}

\author{
Minyoung Kim ${ }^{1,2}$, Seunghwan Lee ${ }^{2}$ and Heung-Sik Lee ${ }^{1 *}$ \\ ${ }^{1}$ Plant Quarantine Technology Center, Animal, Plant and Fisheries Quarantine and Inspection Agency, Suwon 443-400, Korea \\ ${ }^{2}$ Department of Agricultural Biotechnology, Research Institute for Agriculture and Life Science, Seoul National University, \\ 599 Gwanak-ro, Gwanak-gu, Seoul 151-921, Korea

\section{한국미기록 Coleophora virgaureae (나비목: 불나방상과: 통나방과의 보고} \\ 김민영 ${ }^{1,2} \cdot$ 이승환 ${ }^{2} \cdot$ 이흥식 ${ }^{1 *}$ \\ 1농림수산검역검사본부 식물검역기술개발센터, ${ }^{2}$ 서울대학교 농생명공학부
}

\begin{abstract}
Coleophora virgaureae Stainton of Coleophoridae is reported for the first time from Korea, with a description and illustrations of the adult and genitalia are presented based on a single female specimen collected from Mt. Suri, Gyeonggi-do.
\end{abstract}

Key words: Coleophora, Coleophoridae, New record, Korea

초 록: 통나방과의 1종, Coleophora virgaureae Stainton의 국내분포를 처음으로 보고한다. 경기도 수리산에서 채집된 암컷 표본을 근거로 본 종의 종 동정에 필요한 성충과 생식기 사진을 함께 기재한다.

검색어: Coleophora, 통나방과, 미기록종, 한국.

The genus Coleophora Hübner, which belongs to the subfamily Coleophorinae (Lepidoptera: Gelechioidea: Coleophoridae), is commonly known as "casebearers". Larvae construct portable cases and feed on living tissue of various plants, and the pupation takes place in the case (Baldizzone et al., 2006). Constructing behavior and shape of case vary among species, and the related cases are correlated with habitats of host plants.

The family Coleophoridae is subdivided into four subfamilies (Hodges, 1998), with more than 1,340 species worldwide, having a great diversity in the Western Palaearctic and Central

*Comesponding author: lhsgo@korea.kr

Received January 4 2013; Revised January 232013

Accepted February 42013
Asia (Baldizzone et al., 2006). The family Coleophoridae is distinguished from the allied group of families by the following characteristics: i) hindwing with $\mathrm{R}_{\mathrm{s}}$ and $\mathrm{M}_{1}$ separate; ii) hindwing with $\mathrm{M}_{3}$ and $\mathrm{CuA}_{1}$ shape (e.g. separate, connate or stalked); iii) antennal pectin present; iv) valva divided with the costa developed as a free lobe in male genitalia (Hodges, 1998). The genus Coleophora is the largest genus of the family with 1,326 described species (Baldizzone et al., 2006), and it is a single genus in Korea. In Korea, since Park and Baldizzone (1992) had reported 16 species of the genus, Baldizzone and Savenkov (2002) added four species; $C$. adspersella Benander, C. parki Baldizzone \& Savenkov, C. sternipennella (Zetterstedt), and C. ulmivorella Oku. Recently, Kim and Park (2009) reviewed the genus Coleophora in Korea, reporting 27 species. 
In this study, $C$. virgaureae Stainton is reported for the first time from Korea. External morphology including adult and genitalia of this species are examined and illustrated.

\section{Materials and Methods}

The material examined is deposited in the Korea National Arboretum (KNAE), Pocheon, Korea. Wing patterns, external structures and genital characters were examined, and digital images were made with Image Lab. Ver. 2.2.4.0 by MCM design Ltd. Color standard for the description of adults follows Kornerup and Wanscher (1978), and the terminology for the genitalia follows Razowski (1989).

\section{Systematic account}

Order Lepidoptera Linnaeus, 1758

Family Coleophoridae Hübner, [1825]

Genus Coleophora Hübner, 1822, Type species: Tinea anatipennella Hübner, 1796.

Genus Coleophora was established by Hübner, based on Tinea anatipennella. In adult, head smooth-scaled; labial palpi recurved; maxillary palpi minute, 2-segmented. Wings usually very elongated and hindwing spindle-shaped with long fringes. Maculation shades of brown or gray, sometimes mostly white, and unicolorous or with various marking or stripes, but rarely more colorful and with iridescence. Abdomen with paired patchs of short, chitinous spines on the dorsal surface of segments fully exposed in Coleophora, but concealed by overlying scales in other genera. In some species the dorsal surface of the first abdominal segment may display peg like spines bordering a broad shield.

\section{Coleophora virgaureae Stainton, 1857 취통나방 (신칭)}

\section{(Fig. 1)}

Coleophora virgaureae Stainton, 1857, Ent. Ann., 1857:

105; Razowski, 1990: 124-125; Roweck and Savenkov, 2002:

201-218. Type locality: Niemcy, Germany.

Coleophora virgaureella Doubleday, 1859: 33.

Coleophora cinerea Toll, 1953: 103.
Diagnosis. This species is similar to Coleophora cristata Baldizzone in the superficial and in the genitalia structure, but it clearly differs from the latter by the transtilla is smaller with a sharper point in the dorsal margin; sacculus is broader with the longer and weaker teeth in the dorso-caudal angle; the shorter aedeagus with thinner dorsal process in the male genitalia; ductus bursae longer and thinner; signum rather strong thorn-like, pointed apically in the female genitalia.

Adult (Fig. 1a, 1b). Wingspan 12.0-15.0 mm. Head, thorax and abdomen reddish brown. Labial palps white, suffused with reddish scales on outer surface. Antenna entirely white, with the exception of a short tuft of reddish hairs at the base of the first segment. Forewing light ash brown, streaked reddish along the veins, with brown scales in the apical area. Fringes white at apex and light brown at the dorsal costa. Hindwing ash brown.

Male genitalia. Unavailable in this study.

Female genitalia (Fig. 1c). Papillae analis small, narrow and elongate; apophyses posteriores about twice the length of the apophyses anteriores. Ostium bursae bulb-like on left side, narrow, and opening at the distal margin. The ductus bursae very long, about ten times longer the subgenital plate; in its first part it is covered with tiny conical spines in two bands, the remainder of the ductus bursae is transparent and shows many coils. Corpus bursae membranous; signum thorn-like and very sharp.

Material examined. 1 Q , Mt. Suri, Gunpo, 7.X.2000 (Bae, Park, Lee \& Kim), genitalia slide no. 5231.

Host plant. Aster tripolium L. and Solidago virgaurea L. (Asteraceae) (Emmet, 1996).

Distribution. Korea (new record), Japan (Honshu, Shikoku, and Kyushu), Kazakhstan, Caucasus, Siberia eastward to Baikal area, Altai, Europe (except the Balkan Peninsula).

\section{Acknowledgments}

Authors are grateful to Dr. G. Baldizzone, Asti, Italy, for his 

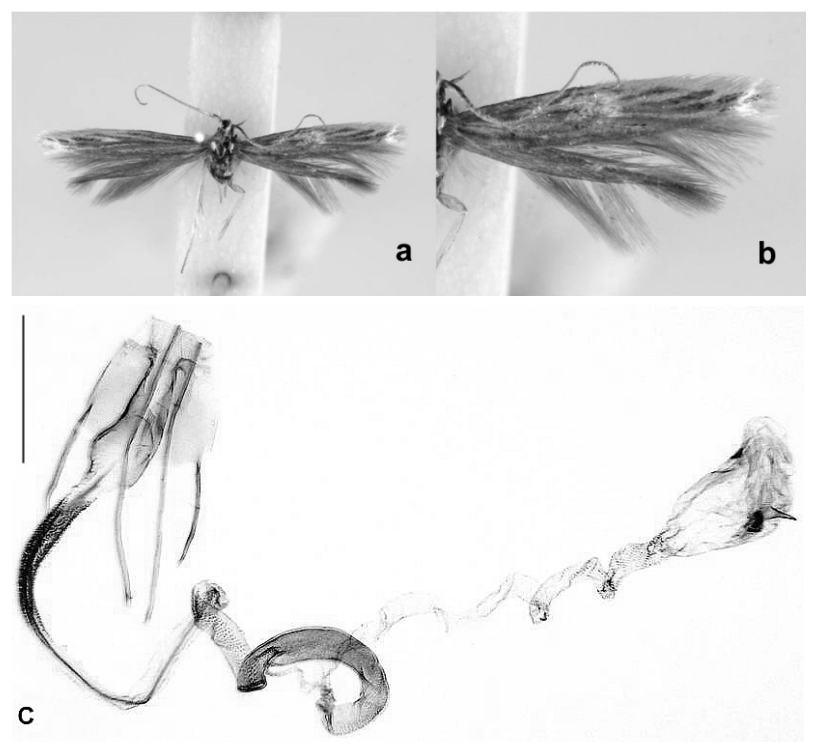

Fig. 1. Coleophora virgaureae Stainton. a. adult; b. wing pattern; c. female genitalia (Scale bar: $1.0 \mathrm{~mm}$ ).

help in identifying the specimen and Dr. K. T. Park, McGuire Center for Lepidoptera and Biodiversity, Florida Museum of Natural History, University of Florida, Gainesville, USA, for his valuable comments.

\section{Literature Cited}

Baldizzone, G., Savenkov, N., 2002. Casebearers (Lepidoptera: Coleophoridae) of the Far East region of Russia. I. (Contribution to the knowledge of the Eastern Palaearctic Insects 12). Beitr. Ent. 52, 367-405.

Baldizzone, G., Wolf van der H., Landry, J.F., 2006. Coleophor- idae, Coleophorinae (Lepidoptera). In: World Catalogue of Insects Vol. 8. Apollo Books Aps., Stenstrup, Denmark, pp. 215.

Doubleday, H., 1859. The zoologist synonymic list of British butterflies and moths. The arrangement and nomenclature by $\mathrm{M}$. Guenée. Edward Newman, London. pp. 33.

Emmet, A.M., 1996. The moths and butterflies of Great Britain and Ireland; Vol 3. [Yponomeutidae - Elachistidae]. Harley Books, Colchester. pp. 452.

Hodges, R.W., 1998. The Gelechioidea. pp. 131-158 in: Kristensen, N.P. (Eds.), Lepidoptera, moths and butterflies. Vol.1: Evolution, systematics, and biogeography. Handbuch der Zoologie/Handbook of Zoology, Vol.IV, Arthropoda: Insecta, Part 35. Walter de Gruyter, Berlin and New York. pp. 491.

Kim, M.Y., Park, K.T., 2009. A Taxonomic review of the genus Coleophora Hübner (Lepidoptera: Coleophoridae) in Korea. J. Asia Pac. Entomol. 12, 183-198.

Kornerup, A., Wanscher, J.H., 1978. Methuen Handbook of Color, 3rd ed. Methuen, London. pp. 252.

Park, K.T., Baldizzone, G., 1992. Systematics of Coleophoridae (Lepidoptera) in Korea. Korean J. Appl. Entomol. 31, 516-535. Razowski, J., 1989. Genitalia terminology in Coleophoridae. Nota lepid. 12, 192-197.

Razowski, J., 1990. Motyle (Lepidoptera) polski, Część XVI Coleophoridae. Monografie Fauny Polski 18. Polska Akademia Nauk, Warszawa, Kraków. pp. 270.

Roweck, H., Savenkov, N., 2002. Erganzungen zur Schmetterlingsfauna (Lepidoptera) von Schleswig-Holstein und Hamburg. Faunistisch-Okologische Mitteilungen 8, 201-218.

Stainton, H.T., 1857. New British species in 1856. Entomologists Annu. 1857, 97-112.

Toll, S., 1953. Rodzina Eupistidae polski. Documenta Physiographica Poloniae 32 [1952]. pp 103. 